\title{
ARE ERROR CORRECTION MODELS THE BEST ALTERNATIVE TO ASSESS CAPITAL MOBILITY IN DEVELOPING COUNTRIES?
}

\author{
Fabiana Rocha ${ }^{\S}$
}

\begin{abstract}
RESUMO
Jansen (1996) e Jansen e Schulze (1996), baseados numa amostra de países desenvolvidos, argumentam que um modelo de correção de erros seria a especificação correta para estimar a correlação poupança-investimento. O objetivo deste artigo é verificar se o mesmo argumento pode ser feito usando-se uma amostra de países em desenvolvimento. Quando se trata de países em desenvolvimento, um modelo de correção de erros é, de fato, superior? Quão sério é o viés potencial das regressões em níveis e em primeiras diferenças relativamente ao modelo de correção de erros? Embora a teoria implique a existência de uma relação de longo prazo entre poupança e investimento, este não parece ser o caso para a maioria dos países em desenvolvimento. Então, a equação em diferenças não tem problema de especificação. Baseado nesta equação, encontra-se evidência de um grau intermediário de mobilidade de capitais em países em desenvolvimento, de acordo com o critério de Feldstein e Horioka.
\end{abstract}

Palavras-chave: solvência, modelo de correção de erros, países em desenvolvimento.

\begin{abstract}
Jansen (1996) and Jansen and Schulze (1996), based on a sample of developed countries argue that an error correction model would be the correct specification to estimate saving-investment correlations. The purpose of this paper is to verify if the same claim can be made using a sample of developing countries. Regarding developing countries is an error correction model indeed superior, as suggested by Jansen and Jansen and Schulze? How serious is the potential bias from using regressions in levels and in first differences instead of an error correction model? Although the theory implies that there is a long-run relationship between saving and investment, this does not seem to be the case for the majority of the developing economies individually. Therefore, the equation in differences is not poorly specified. Based on this equation it seems to be an intermediate degree of capital mobility in developing countries according to the criterion of Feldstein and Horioka.
\end{abstract}

Key words: solvency, error correction models, developing countries.

JEL classification: F2, F3.

$\S$ Universidade de São Paulo. Endereço para contato: FEA-USP - Av. Prof. Luciano Gualberto, 908 - Cidade Universitária - São Paulo-SP - CEP 05508-010. E-mail: frocha@usp.br.

Recebido em maio de 2005. Aceito em dezembro de 2005. 


\section{INTRODUCTION}

Feldstein and Horioka (1980) suggested the correlation between saving and investment as a measure of the degree of capital mobility. Based on a sample of 16 OECD countries, they obtained evidence that saving and investment were highly correlated and concluded that the degree of capital mobility in industrialized countries was low, going against accepted wisdom that these countries had few restrictions on capital flows. Besides this, the estimated correlation was extremely stable over time, despite the belief that capital mobility had increased after the mid-1970s. Murphy (1984), Obstfeld (1986), Dooley et al. (1987) and Wong (1990) also found evidence of an association between saving and investment for less industrialized and developing countries, although the estimated correlations are on average lower. Nevertheless, the estimated correlations are also lower in the period before the mid-70s than afterward. The regularity of the results has made the saving-investment correlation of Feldstein and Horioka one of the most important puzzles in international macroeconomics. (Obstfeld and Rogoff, 2000).

The initial regressions were done using cross-section data. As observed by Wong (1990), this brings a serious problem of sample selection bias. To deal with this problem, various authors have estimated the saving-investment correlation for individual countries using time series, doing the regressions with the variables in levels and/ or first differences. More recently, unit root and cointegration techniques have been used in three main approaches. The first starts from the observation that if saving and investment are I(1), the hypothesis of Feldstein and Horioka of perfect correlation can be reinterpreted as the hypothesis that saving and investment are cointegrated with a (1,1)' cointegration vector. The second is based on the additional claim that the difference between national saving and investment is, from an accounting standpoint, equal to the current account balance of payments. Hence, the cointegration between saving and investment implies that the saving-investment linear combination, or the current account balance, is $\mathrm{I}(0)$. In this form, if the hypothesis that the current account balance is $\mathrm{I}(1)$ cannot be rejected, one can conclude that there is some degree of capital mobility. Finally, the third approach argues that an error correction model is the correct specification, for two reasons. First, investment and saving should be nonstationary variables. Second, investment and saving are bound by the intertemporal budget constraint, i.e., are cointegrated. Variables that exhibit these two characteristics must be specified using an error correction model (Engle and Granger, 1987). Besides this, as observed by Jansen (1996) and Jansen and Schulze (1996), an error correction model would be a synthesis of the other approaches in the literature, which focus either on the long-run relation (cointegration) or only on the short-term one (estimates of from the original Feldstein and Horioka regressions, in levels or first differences).

The purpose of this paper is to deal with the Feldstein-Horioka puzzle from a methodological point of view. Given the serious criticisms of the cross-section estimations, what can be said using a time series approach? Is it possible to get a common result using the three approaches described above? If not, is an error correction model indeed better, as suggested by Jansen (1996) and Jansen and Schulze (1996)? How serious is the potential bias from using regressions in levels and in first differences instead of an error correction model? In order to do this, we employ a sample of 22 developing countries during the period 1960-1996. There are two reasons for this choice. First, the available evidence for developing countries is relatively scarce and controversial. Second, we are not aware of studies that explicitly assess the cointegration between saving and investment for these countries.

The paper is organized as follows. The second section discusses the different econometric specifications used to measure the saving-investment correlation in developing countries. The third section 
presents the results of the estimations from the error correction model. The fourth section compares the results of the different approaches, and the fifth section summarizes the main conclusions.

\section{THE FELDSTEIN-HORIOKA EQUATION AND ITS DIFFERENT ECONOMETRIC SPECI- FICATIONS}

Following Feldstein and Horioka (1980), Dooley et al. (1987) propose evaluating the degree of capital mobility through the correlation between saving and investment, estimating the following regression using cross-section data for developing countries:

$$
(I / Y)_{i}=a+b(S / Y)_{i}+u_{i}
$$

where $(I / Y)$ is the ratio between gross domestic investment and gross national product (GNP), $(S / Y)$ is the ratio between gross domestic saving and GNP, $i$ is a country index, $a$ and $b$ represent parameters to be estimated, and $u$ is an error term. For small countries, $b$ should be near zero under the hypothesis of perfect capital mobility. When $b$ is equal to zero there is no relation between domestic saving and investment. On the other hand, if $b$ is large, capital should be highly immobile. If $b$ is equal to 1 , for example, all additional saving is used to finance domestic investment.

Given that I/Y and S/Y are pro-cyclical, annual data will imply an upward bias in the coefficient b. Averaged data, then, is used in order to eliminate the effects of the economic cycle (see, among others, Bayoumi, 1990).

Equation (2.1) also has also been estimated using time series for developing countries individually. The use of time series instead of cross sections should bring two advantages. First, it avoids the problem of sample selection bias typical of cross-section studies. (Wong, 1990). Second, it avoids bias against capital mobility resulting from the correlation between saving and investment introduced by using averaged data in an intertemporal context. (Sinn, 1992). By the solvency condition, a country cannot take or make loans indefinitely, i.e., current account surpluses (deficits) must be followed at some point by corresponding deficits (surpluses). By definition, a country's current account balance in a period is equal to the difference between its investment and saving. Given that the sum of the current account balances should be zero over the long run, the same should occur with the difference between saving and investment. Since the long-run means of the saving/GNP and investment/GNP ratios are approximately equal, the use of averaged data introduces a correlation between these two variables. Hence, cross-section regressions employing averaged data will erroneously signal a low level of capital mobility.

Montiel (1994) uses variables in levels:

$$
(I / Y)_{t}=a+b(S / Y)_{t}+u_{t}
$$

1 Various reasons have been given to explain why saving and investment might be correlated even in the presence of capital mobility. Summers (1988) and Obstfeld (1986) point to population growth and shocks to productivity, while Murphy (1986) and Wong (1990) put forward nontradable goods and immobile factors. Besides this, if governments have a current account target, a positive correlation between saving and investment can appear irrespective of capital mobility. (Summers, 1988; Bayoumi, 1990). To hit the current account target when faced with a deficit, the government can resort to a tight fiscal policy. Since national saving is the sum of public and private saving, national saving becomes endogenous through its public component. Tobin (1983) and Murphy (1984) present a country-size effect. Exogenous changes in the saving of a large country can affect the world interest rate, and investment as well, causing a co-movement between saving and investment. 
Because this specification ignores the process of dynamic adjustment, it cannot adequately capture the saving-investment dynamic.

Therefore, Montiel (1994) also estimates the equation in first differences:

$$
\Delta(I / Y)_{t}=a+b \Delta(S / Y)_{t}+u_{t}
$$

The idea behind working with first differences is to make the series stationary. However, unless there is no long-run relationship (cointegration) between saving and investment, equation (2.3) is poorly specified (it is over-identified). Since saving can be an endogenous variable, implying inconsistent estimates for both equations (2.2) and (2.3), they were estimated using ordinary least squares and instrumental variables.

With temporal data, it is necessary first to check whether $I / Y$ and $S / Y$ are not stationary. If this is the case, i.e., $I / Y$ and $S / Y$ are $\mathrm{I}(1)$, the Feldstein-Horioka test implies that $S / Y$ and $I / Y$ are cointegrated with a $(1,-1)$ ' cointegration vector. (Gundlach and Sinn, 1992).

The hypothesis that $S / Y$ and $I / Y$ are cointegrated with a $(1,-1)^{\prime}$ cointegration vector in turn implies that the linear combination of $S / Y-I / Y$ is $\mathrm{I}(0)$. Given that by definition the current account is equal to the difference between saving and investment, if it is not posible to reject the hypothesis of non-stationarity of the current account, there is capital mobility. Bagnai and Manzocchi (1996) investigate whether or not the current account balance of 37 developing countries capital was stationary and conclude that in 14 of the 37 countries in the sample there is some degree of mobility.

Mamingi (1997) tests for cointegration using an error correction model. Montiel (1994) simply assumes that saving and investment are cointegrated given that the solvency condition does not allow these to diverge permanently. Mamingi (1997) estimates a time-series version of equation (2.1) adopting the fully modified OLS estimator (Phillips and Hansen, 1990), since this corrects for endogeneity and serial correlation and asymptotically eliminates sample bias. Montiel (1994), in turn, estimates the following error correction model employing ordinary least squares and instrumental variables:

$$
\Delta i_{t}=b \Delta s_{t}+\lambda\left(i_{t-1}-\hat{\beta} s_{t}\right)+\varepsilon_{t}
$$

where $i=(I / Y), s=(S / Y), b$ and $\lambda$ are constant parameters with $b<\hat{\beta}$ and $-1<\lambda<0$, and $\hat{\beta}$ is the least squares and instrumental variables estimates from equation (2.1).

The results based on time series indicate that capital mobility in developing countries is greater than expected, although there is no consensus regarding the extent of this mobility in each country individually (Table 1). As can be observed, only two of the 19 countries (Israel and S. Korea) are equally classified by Mamingi (1997), Montiel (1994) and Bagnai and Manzocchi (1996). On the other hand, the degrees of capital mobility of six countries (Ecuador, Guatemala, India, Malawi, Senegal and Thailand) are classified differently by the three authors. 
Table 1 - Capital mobility in developing countries: some previous results

\begin{tabular}{llll}
\hline Country & \multicolumn{1}{c}{ Mamingi } & Montiel & Bagnai/Manzocchi \\
Many intervals & Many intervals \\
\hline Argentina & $1970-1991$ & Inconclusive & Immobility \\
Brazil & Intermediate & Mobility & Mobility \\
Chile & Intermediate & Immobility & Immobility \\
Colombia & Mobility & Mobility & Immobility \\
Ecuador & Intermediate & Mobility & Immobility \\
Guatemala & Immobility & Inconclusive & Mobility \\
Honduras & Immobility & Inconclusive & Immobility \\
India & Intermediate & Inconclusive & Mobility \\
Indonesia & & Inconclusive & Immobility \\
Israel & Mobility & Mobility & Mobility \\
Jamaica & Immobility & Mobility & Immobility \\
S. Korea & Mobility & Mobility & Mobility \\
Malawi & Immobility & Inconclusive & Mobility \\
Nigeria & Intermediate & Immobility & Immobility \\
Paraguay & Mobility & Mobility & Mobility \\
Philippines & Immobility & Intermediate & Immobility \\
Senegal & Intermediate & Mobility & Immobility \\
Thailand & Mobility & Inconclusive & Mobility \\
Venezuela & Mobility & Immobility & Immobility \\
\hline
\end{tabular}

Notes: Previous results are shown only for the countries that will be analyzed later in this work.

"Intermediate" indicates that both the hypothesis of perfect mobility as well as that of perfect immobility were rejected; "mobility" means that only the hypothesis of perfect capital mobility was not rejected; "immobility" indicates that only the hypothesis of perfect immobility was not rejected; and "inconclusive" means that it was not possible to discriminate between mobility and immobility.

Source: Mamingi (1997, Table 5); Montiel (1994, Table 2), results of the estimates using instrumental variables; Bagnai and Manzoocchi (1996, Table 2).

\section{ERROR CORRECTION MODEL: DISCUSSION OF EMPIRICAL RESULTS}

Jansen (1996) and Jansen and Schulze (1996), argue that the error correction model is the only specification with theoretical support. Given that in steady state $I / Y=S / Y$ that is, the current account is in equilibrium over the long run because of the solvency condition, the dynamics of saving and investment is temporary. An error correction model, then, is the best alternative to model the problem since it consists of a dynamic equation with a steady-state solution that is compatible with the equilibrium. Additionally, the error correction model includes the other specifications as special cases.

They consider the following specification:

$$
\Delta i_{t}=\alpha+\beta \Delta s_{t}+\gamma\left(s_{t-1}-i_{t-1}\right)+\delta s_{t-1}+\varepsilon_{t}
$$

where $\varepsilon$ is a well-behaved error term. The parameter of interest is $\beta$. It measures the movements of saving and investment in response to shocks that affect the economy. The error correction term $s_{t-1}-i_{t-1}$ captures the long-term relationship. Saving and investment are cointegrated only if $\gamma \neq$ 0 . The cointegration or long-run relationship is given by: 


$$
\alpha+\gamma(\bar{s}-\bar{i})+\delta \bar{s}=0
$$

The cointegration vector is $(1+\delta / \gamma,-1)^{\prime}$. If $\delta=0$, the current account $(s-i)$ is a variable that is stationary around $-\alpha / \gamma$. The current account fluctuates around zero if $\alpha=\delta=0$.

Equation (3.1) can then be seen as a synthesis of the other approaches in the literature. Equation (2.2), which performs the regression with the variables in levels, is a static equation and therefore is conceptually comparable to the long-run relation (3.2). Equation (2.2) can be obtained from equation (3.1) by making $\beta-\delta=1$ and $\gamma=1$. Equation (2.3), in turn, measures the short-run correlation but has no solution in the long run because the levels of saving and investment in steady state are indeterminate. ${ }^{2}$ Equation (2.3) is obtained from equation (3.1) by making $\gamma=\delta=0 .{ }^{3}$ Besides estimating the short-term dynamic, the error correction model also simultaneously estimates the long-run dynamic. In this way, equation (3.1) also takes into account the long-run relation between saving and investment that the recent application of cointegration techniques to the assessment of capital mobility tries to capture. Testing whether $\gamma=0$ is the same as testing for cointegration.

Jansen (1996) and Jansen and Schulze (1996) suggest the following steps to detect capital mobility using an error correction model:

1. Non-rejection of $\gamma=0$ implies that saving and investment are not cointegrated. This constitutes evidence of capital mobility according to the criterion of Feldstein and Horioka, as long as saving and investment are not correlated. If $\gamma$ is really equal to zero, it is not necessary to evaluate $\beta$ and $\delta$.

2. Rejection of $\gamma=0$ implies that there is a relationship between saving and investment. The estimate of $\delta$ will determine the type of this relationship. If $\delta=0$, the current account (saving minus investment) is a constant in the long run $(-\alpha / \gamma)$, i.e., the current account is stationary around $-\alpha / \gamma$. This result is typical of intertemporal equilibrium models that explicitly assume perfect capital mobility. In this case, it is not possible to reach any conclusion regarding the degree of capital mobility. If $\delta \neq 0$, saving and investment are not cointegrated with vector $(1,-1)^{\prime}$ but with vector $(1+\delta / \gamma,-1)^{\prime}$. The current account balance, therefore, is a nonstationary variable and there is evidence in favor of capital mobility.

3. If there is cointegration $(\gamma \neq 0)$ and $\delta=0$, the next step is to estimate the short-run correlation, $\beta$.

The sample consists of a set of annual observations of the ratios of investment and saving from 1960 to 1996 for 22 developing countries: Argentina, Brazil, Chile, Colombia, S. Korea, Ecuador, Philippines, Ghana, Guatemala, Honduras, Hong Kong, India, Indonesia, Israel, Jamaica, Malawi, Nigeria, Pakistan, Paraguay, Senegal, Thailand and Venezuela. The data come from the World Bank Indicators (1998). Domestic investment is defined as gross investment by the private sector and by the government, and domestic saving as private-sector plus government saving. Both are divided by the gross national product to obtain investment and saving ratios.

In the appendix we summarize the augmented Dickey-Fuller (ADF) test for stationarity of investment and saving. Both variables appear to be nonstationary in levels according to the ADF test, except saving in Colombia and India. A widely used alternative to the ADF test is the PhillipsPerron (PP) test. Even using this test, the results for saving ratios in Colombia and India do not change. As the null hypothesis is rejected only at the 5\% significance level, we consider that saving

2 Leachman (1991) observes that equation (2.3) is the correct specification only if saving and investment are not cointegrated. If they are cointegrated, equation (2.3) is over-differentiated and poorly specified, causing bias.

3 Since equations (2.2) and (2.3) are encompassed by the error correction model, one can test the validity of these specifications through standard parameter restriction tests. 
in these two countries are not stationary. Although the results are not reported in the table, both variables appear to be first-difference stationary for all the countries in the sample.

Initialy, we use the same specification as Montiel (1994), i.e., the same equation as Jansen (1996) and Jansen and Schulze (1996) except for the term $s_{t-1}$, which is disregarded.

$$
\Delta i_{t}=\alpha+\beta \Delta s_{t}+\gamma\left(s_{t-1}-i_{t-1}\right)+\varepsilon_{t}
$$

Table 2 summarizes the estimations.

The first step is to discuss the estimates of $\gamma$. The associated t statistic $\left(t_{E C M}\right)$ is a cointegration test statistic. Kremers et al. (1992) show that $t_{E C M}$ follows the normal distribution in large samples. Using a standard normal distribution table and performing a single-tailed test at the $5 \%$ significance level, based on the critical value 2.57, it is possible to reject the hypothesis of no cointegration for Chile, Guatemala, Honduras, Jamaica, Malawi, Paraguay, Senegal, Thailand and Venezuela. For small samples, they recommend using the critical values of the Dickey-Fuller distribution, which are higher. At these values it is possible to reject non-cointegration only for Chile. According to Jansen (1996), absence of cointegration implies capital mobility.

Once the steady-state relationship is analyzed, the next step is to assess the short-run dynamics of saving and investment captured by the coefficient $\beta$. Except for Colombia, Guatemala, Hong Kong, Israel, Nigeria and Venezuela, the other countries have a saving-investment correlation different from zero. All the countries have a correlation significantly different from one except India. The mean estimate of $\beta$ is 0.42 (when only the positive correlations are considered, i.e., when Ecuador and Venezuela are disregarded).

Theoretical models show that the sign and size of the short-run correlation depends on the nature of the errors and the structure of the economy. (Finn, 1990; Baxter and Crucini, 1993). Therefore, the differences between the saving-investment correlations of the countries that make up the sample are fully compatible with what is expected from the theory. Besides this, these differences supply an additional empirical argument against the cross-section regressions, which assume that the saving-investment correlation is the same for each of the countries in the sample.

Using the original criterion of Feldstein and Horioka, one can conclude, then, that in Colombia, Guatemala, Hong Kong, Israel and Nigeria capital can be considered mobile since only the hypothesis of perfect capital mobility $(\beta=0)$ was not rejected. Only in India can capital be considered immobile, since only the hypothesis of perfect immobility $(\beta=1)$ was rejected.

The LM tests indicate that there is no autocorrelation, the ARCH test implies that the errors are homoskedastic and the Jarque-Bera test reveals that in most of the cases the errors are normally distributed.

For purposes of comparison, we also estimate the error correction model proposed by Jansen (1996) and Jansen and Schulze (1996), i.e., equation (3.1). The results of the estimations are presented in Table 3.

The results for short-run coefficients remain the same, but there is evidence of cointegration also for Colombia, S. Korea, Ecuador, Nigeria, Pakistan and Thailand. The values of $\beta$ do not vary much and the conclusions remain valid. The diagnostic tests indicate, in the majority of the cases, no autocorrelation, homoskedasticity, and normality of the errors. 
Table 2 - Results of the estimation of the error correction model

\begin{tabular}{|c|c|c|c|c|c|c|c|c|}
\hline Country & Constant & $\Delta s_{t}$ & $(s-i)_{t-1}$ & $\bar{R}^{2}$ & LM(1) & LM(2) & $\mathrm{ARCH}$ & $J B$ \\
\hline Argentina & $\begin{array}{l}-0.0037 \\
(-1.157)\end{array}$ & $\begin{array}{l}0.6444 \\
(6.278)\end{array}$ & $\begin{array}{l}0.2914 \\
(2.147)\end{array}$ & 0.5169 & $\begin{array}{r}1.1901 \\
(0.2834)\end{array}$ & $\begin{array}{r}1.2367 \\
(0.3042)\end{array}$ & $\begin{array}{r}0.0035 \\
(0.9534)\end{array}$ & $\begin{array}{r}0.9795 \\
(0.6128)\end{array}$ \\
\hline Brazil & $\begin{array}{l}-0.0005 \\
(-0.234)\end{array}$ & $\begin{array}{l}0.6316 \\
(6.327)\end{array}$ & $\begin{array}{l}0.1826 \\
(2.015)\end{array}$ & 0.5366 & $\begin{array}{r}3.5457 \\
(0.0688)\end{array}$ & $\begin{array}{r}2.0208 \\
(0.1496)\end{array}$ & $\begin{array}{r}0.1334 \\
(0.7123)\end{array}$ & $\begin{array}{r}5.1148 \\
(0.0775)\end{array}$ \\
\hline Chile & $\begin{array}{l}0.0010 \\
(0.244)\end{array}$ & $\begin{array}{l}0.6449 \\
(6.882)\end{array}$ & $\begin{array}{l}0.4715 \\
(3.797)\end{array}$ & 0.6257 & $\begin{array}{r}0.3057 \\
(0.5841)\end{array}$ & $\begin{array}{r}2.8881 \\
(0.0708)\end{array}$ & $\begin{array}{r}2.6400 \\
(0.1137)\end{array}$ & $\begin{array}{r}1.2351 \\
(0.5393)\end{array}$ \\
\hline Colombia & $\begin{array}{l}-0.0001 \\
(-0.043)\end{array}$ & $\begin{array}{l}0.2250 \\
(1.376)\end{array}$ & $\begin{array}{r}0.1679 \\
(1.633)\end{array}$ & 0.1000 & $\begin{array}{r}0.7921 \\
(0.3801)\end{array}$ & $\begin{array}{r}0.4596 \\
(0.6358)\end{array}$ & $\begin{array}{r}0.2034 \\
(0.6549)\end{array}$ & $\begin{array}{r}0.1329 \\
(0.5393)\end{array}$ \\
\hline S. Korea & $\begin{array}{c}0.0086 \\
(1.458)\end{array}$ & $\begin{array}{l}0.5466 \\
(2.781)\end{array}$ & $\begin{array}{c}0.1443 \\
(1.743)\end{array}$ & 0.1913 & $\begin{array}{r}1.1644 \\
(0.2886)\end{array}$ & $\begin{array}{r}2.0796 \\
(0.1420)\end{array}$ & $\begin{array}{r}1.1423 \\
(0.2929)\end{array}$ & $\begin{array}{r}1.1508 \\
(0.5624)\end{array}$ \\
\hline Ecuador & $\begin{array}{l}0.0032 \\
(0.783)\end{array}$ & $\begin{array}{l}-0.0928 \\
(-0.559)\end{array}$ & $\begin{array}{l}0.2321 \\
(2.086)\end{array}$ & 0.1140 & $\begin{array}{r}0.1622 \\
(0.6898)\end{array}$ & $\begin{array}{r}1.5832 \\
(0.2214)\end{array}$ & $\begin{array}{r}0.1931 \\
(0.6632)\end{array}$ & $\begin{array}{r}7.6047 \\
(0.0223)\end{array}$ \\
\hline Philippines & $\begin{array}{l}0.0091 \\
(1.913)\end{array}$ & $\begin{array}{l}0.4304 \\
(2.472)\end{array}$ & $\begin{array}{l}0.2902 \\
(2.409)\end{array}$ & 0.2159 & $\begin{array}{r}4.0729 \\
(0.0520)\end{array}$ & $\begin{array}{r}2.9037 \\
(0.0698)\end{array}$ & $\begin{array}{r}8.2589 \\
(0.0070)\end{array}$ & $\begin{array}{r}1.8823 \\
(0.3901)\end{array}$ \\
\hline Ghana & $\begin{array}{l}0.0049 \\
(0.847)\end{array}$ & $\begin{array}{l}0.3283 \\
(2.493)\end{array}$ & $\begin{array}{l}0.1362 \\
(1.464)\end{array}$ & 0.1247 & $\begin{array}{r}0.0028 \\
(0.9583)\end{array}$ & $\begin{array}{r}0.1593 \\
(0.8534)\end{array}$ & $\begin{array}{r}1.4614 \\
(0.2353)\end{array}$ & $\begin{array}{r}6.6145 \\
(0.0366)\end{array}$ \\
\hline Guatemala & $\begin{array}{l}0.0145 \\
(2.740)\end{array}$ & $\begin{array}{l}0.2546 \\
(1.167)\end{array}$ & $\begin{array}{l}0.4392 \\
(3.420)\end{array}$ & 0.2299 & $\begin{array}{r}0.4929 \\
(0.4877)\end{array}$ & $\begin{array}{r}0.2394 \\
(0.7885)\end{array}$ & $\begin{array}{r}0.7632 \\
(0.3886)\end{array}$ & $\begin{array}{c}0.4713^{\circ} \\
(0.7900)\end{array}$ \\
\hline Honduras & $\begin{array}{l}0.0207 \\
(2.801)\end{array}$ & $\begin{array}{l}0.6598 \\
(3.888)\end{array}$ & $\begin{array}{l}0.4403 \\
(3.147)\end{array}$ & 0.3647 & $\begin{array}{r}1.9501 \\
(0.1721)\end{array}$ & $\begin{array}{r}3.0987 \\
(0.0593)\end{array}$ & $\begin{array}{r}0.0418 \\
(0.8392)\end{array}$ & $\begin{array}{r}7.9384 \\
(0.0188)\end{array}$ \\
\hline Hong Kong & $\begin{array}{l}-0.0057 \\
(-0.921)\end{array}$ & $\begin{array}{c}0.1145 \\
(0.816)\end{array}$ & $\begin{array}{l}0.2221 \\
(2.438)\end{array}$ & 0.1036 & $\begin{array}{r}2.3162 \\
(0.1378)\end{array}$ & $\begin{array}{r}1.1497 \\
(0.3298)\end{array}$ & $\begin{array}{r}3.3381 \\
(0.0767)\end{array}$ & $\begin{array}{r}1.0565 \\
(0.5896)\end{array}$ \\
\hline India & $\begin{array}{r}0.0049 \\
(1.960\end{array}$ & $\begin{array}{l}0.9840 \\
(9.450)\end{array}$ & $\begin{array}{l}0.2672 \\
(2.272)\end{array}$ & 0.7239 & $\begin{array}{r}1.6076 \\
(0.2139)\end{array}$ & $\begin{array}{r}1.1371 \\
(0.3337)\end{array}$ & $\begin{array}{r}0.0929 \\
(0.7624)\end{array}$ & $\begin{array}{r}0.5621 \\
(0.7549)\end{array}$ \\
\hline Indonesia & $\begin{array}{l}0.0020 \\
(0.469)\end{array}$ & $\begin{array}{l}0.3302 \\
(3.117)\end{array}$ & $\begin{array}{c}0.1261 \\
(1.279)\end{array}$ & 0.1807 & $\begin{array}{r}2.0196 \\
(0.1649)\end{array}$ & $\begin{array}{r}4.9411 \\
(0.0137)\end{array}$ & $\begin{array}{r}0.2928 \\
(0.5920)\end{array}$ & $\begin{array}{r}1.3042 \\
(0.5209)\end{array}$ \\
\hline Israel & $\begin{array}{l}0.0151 \\
(2.053)\end{array}$ & $\begin{array}{r}0.1511 \\
(1.443)\end{array}$ & $\begin{array}{l}0.1380 \\
(2.298)\end{array}$ & 0.1084 & $\begin{array}{r}0.3461 \\
(0.5604)\end{array}$ & $\begin{array}{r}1.4603 \\
(0.2477)\end{array}$ & $\begin{array}{r}0.8944 \\
(0.3511)\end{array}$ & $\begin{array}{r}4.1667 \\
(0.1245)\end{array}$ \\
\hline Jamaica & $\begin{array}{l}0.0186 \\
(2.455)\end{array}$ & $\begin{array}{l}0.2538 \\
(2.105)\end{array}$ & $\begin{array}{l}0.4018 \\
(3.593)\end{array}$ & 0.2721 & $\begin{array}{r}0.5762 \\
(0.4533)\end{array}$ & $\begin{array}{r}0.3693 \\
(0.6942)\end{array}$ & $\begin{array}{r}0.0637 \\
(0.8023)\end{array}$ & $\begin{array}{r}1.5681 \\
(0.4565)\end{array}$ \\
\hline Malawi & $\begin{array}{l}0.0576 \\
(3.149)\end{array}$ & $\begin{array}{l}0.5452 \\
(3.035)\end{array}$ & $\begin{array}{l}0.5001 \\
(3.448)\end{array}$ & 0.3175 & $\begin{array}{r}0.4333 \\
(0.5151)\end{array}$ & $\begin{array}{r}0.2459 \\
(0.7834)\end{array}$ & $\begin{array}{r}1.0531 \\
(0.3122)\end{array}$ & $\begin{array}{r}1.1765 \\
(0.5552)\end{array}$ \\
\hline Nigeria & $\begin{array}{l}0.0019 \\
(0.312)\end{array}$ & $\begin{array}{l}0.2243 \\
(1.557)\end{array}$ & $\begin{array}{l}0.2919 \\
(2.523)\end{array}$ & 0.1233 & $\begin{array}{r}0.2827 \\
(0.5985)\end{array}$ & $\begin{array}{r}1.1171 \\
(0.3400)\end{array}$ & $\begin{array}{r}0.4078 \\
(0.5274)\end{array}$ & $\begin{array}{r}1.1257 \\
(0.5695)\end{array}$ \\
\hline Pakistan & $\begin{array}{l}0.0089 \\
(1.156)\end{array}$ & $\begin{array}{l}0.3968 \\
(2.822)\end{array}$ & $\begin{array}{l}0.1086 \\
(1.087)\end{array}$ & 0.1463 & $\begin{array}{r}0.0458 \\
(0.8318)\end{array}$ & $\begin{array}{r}0.1677 \\
(0.8464)\end{array}$ & $\begin{array}{r}0.4935 \\
(0.4872)\end{array}$ & $\begin{array}{r}4.0578 \\
(0.1139)\end{array}$ \\
\hline Paraguay & $\begin{array}{l}0.0133 \\
(2.542)\end{array}$ & $\begin{array}{l}0.2741 \\
(2.618)\end{array}$ & $\begin{array}{l}0.3062 \\
(2.878)\end{array}$ & 0.2055 & $\begin{array}{r}4.6517 \\
(0.0390)\end{array}$ & $\begin{array}{r}3.3831 \\
(0.0500)\end{array}$ & $\begin{array}{r}0.1949 \\
(0.6618)\end{array}$ & $\begin{array}{r}0.0463 \\
(0.9771)\end{array}$ \\
\hline Senegal & $\begin{array}{l}0.0139 \\
(2.771)\end{array}$ & $\begin{array}{l}0.2566 \\
(3.685)\end{array}$ & $\begin{array}{l}0.1683 \\
(2.711)\end{array}$ & 0.2934 & $\begin{array}{r}1.4571 \\
(0.2362)\end{array}$ & $\begin{array}{r}2.0229 \\
(0.1493)\end{array}$ & $\begin{array}{r}0.2268 \\
(0.6370)\end{array}$ & $\begin{array}{r}4.3437 \\
(0.1139)\end{array}$ \\
\hline Thailand & $\begin{array}{l}0.0187 \\
(3.377)\end{array}$ & $\begin{array}{l}0.5489 \\
(2.953)\end{array}$ & $\begin{array}{l}0.4512 \\
(3.359)\end{array}$ & 0.3431 & $\begin{array}{r}0.0757 \\
(0.7850)\end{array}$ & $\begin{array}{r}0.0498 \\
(0.9515)\end{array}$ & $\begin{array}{r}0.0079 \\
(0.9299)\end{array}$ & $\begin{array}{r}0.1813 \\
(0.9133)\end{array}$ \\
\hline Venezuela & $\begin{array}{l}-0.0273 \\
(-2.664)\end{array}$ & $\begin{array}{l}-0.1278 \\
(-0.656)\end{array}$ & $\begin{array}{l}0.4352 \\
(3.851)\end{array}$ & 0.2975 & $\begin{array}{r}0.0832 \\
(0.7748)\end{array}$ & $\begin{array}{r}0.9666 \\
(0.3915)\end{array}$ & $\begin{array}{r}0.2363 \\
(0.6301)\end{array}$ & $\begin{array}{r}0.5806 \\
(0.7480)\end{array}$ \\
\hline
\end{tabular}

Notes: $\mathrm{t}$ statistics in parentheses.

$\bar{R}^{2}: R^{2}$ adjusted; LM (i): Lagrange multiplier test for serial correlation of order i (p-value in parentheses); ARCH: first-order test for conditional autoregressive heteroskedasticity ( $\mathrm{p}$-value in parentheses); JB: Jarque-Bera statistic for normality ( $\mathrm{p}$-value in parentheses). 
Table 3 - Results of the estimation from the error correction model specified by Jansen (1996) and Jansen and Schulze (1996)

\begin{tabular}{|c|c|c|c|c|c|c|c|c|c|}
\hline & Constant & $\Delta s_{t}$ & $(s-i)_{t-1}$ & $s_{t-1}$ & $\bar{R}^{2}$ & $\operatorname{LM}(1)$ & $\operatorname{LM}(2)$ & $\mathrm{ARCH}$ & $\mathrm{JB}$ \\
\hline Argentina & $\begin{array}{l}0.0131 \\
(0.806)\end{array}$ & $\begin{array}{c}0.6189 \\
(5.877)\end{array}$ & $\begin{array}{l}0.3259 \\
(2.338)\end{array}$ & $\begin{array}{l}-0.0751 \\
(-1.054)\end{array}$ & 0.5597 & $\begin{array}{r}1.4551 \\
(0.2368)\end{array}$ & $\begin{array}{r}1.0540 \\
(0.3611)\end{array}$ & $\begin{array}{r}0.0004 \\
(0.9849)\end{array}$ & $\begin{array}{r}1.0909 \\
(0.5796)\end{array}$ \\
\hline Brazil & $\begin{array}{l}0.0024 \\
(0.086)\end{array}$ & $\begin{array}{l}0.6254 \\
(5.334)\end{array}$ & $\begin{array}{c}0.1892 \\
(1.695)\end{array}$ & $\begin{array}{l}-0.0139 \\
(-0.105)\end{array}$ & 0.522 & 3.914 & 2.066 & $\begin{array}{r}0.1668 \\
(0.6856)\end{array}$ & 5.380 \\
\hline Chile & $\begin{array}{l}0.0286 \\
(1.524)\end{array}$ & $\begin{array}{l}0.5797 \\
(5.704)\end{array}$ & $\begin{array}{l}0.6485 \\
(3.829)\end{array}$ & $\begin{array}{l}-0.1407 \\
(-1.505)\end{array}$ & 0.6704 & $\begin{array}{r}0.0076 \\
(0.9309)\end{array}$ & $\begin{array}{r}1.4903 \\
(0.2415)\end{array}$ & $\begin{array}{r}2.1223 \\
(0.1546)\end{array}$ & $\begin{array}{r}2.2595 \\
(0.3231)\end{array}$ \\
\hline Colombia & $\begin{array}{l}0.1007 \\
(2.687)\end{array}$ & $\begin{array}{l}0.1050 \\
(0.672)\end{array}$ & $\begin{array}{l}0.5103 \\
(3.228)\end{array}$ & $\begin{array}{l}-0.5331 \\
(-2.698)\end{array}$ & 0.2662 & $\begin{array}{r}0.1916 \\
(0.6647)\end{array}$ & $\begin{array}{r}0.6918 \\
(0.5085)\end{array}$ & $\begin{array}{r}0.0315 \\
(0.86030\end{array}$ & $\begin{array}{r}0.7626 \\
(0.6830)\end{array}$ \\
\hline S. Korea & $\begin{array}{l}0.0670 \\
(2.778)\end{array}$ & $\begin{array}{l}0.3275 \\
(1.614)\end{array}$ & $\begin{array}{l}0.4532 \\
(3.098)\end{array}$ & $\begin{array}{l}-0.1875 \\
(-2.483)\end{array}$ & 0.3007 & $\begin{array}{r}1.7072 \\
(0.2009)\end{array}$ & $\begin{array}{r}0.4848 \\
(0.6205)\end{array}$ & $\begin{array}{r}0.2244 \\
(0.6387)\end{array}$ & $\begin{array}{r}0.8581 \\
(0.6511)\end{array}$ \\
\hline Ecuador & $\begin{array}{l}0.0418 \\
(2.078)\end{array}$ & $\begin{array}{l}-0.1036 \\
(-0.650)\end{array}$ & $\begin{array}{l}0.3999 \\
(2.919)\end{array}$ & $\begin{array}{l}-0.1932 \\
(-1.955)\end{array}$ & 0.1838 & $\begin{array}{r}1.1470 \\
(0.2924)\end{array}$ & $\begin{array}{r}1.1542 \\
(0.3289)\end{array}$ & $\begin{array}{r}1.2879 \\
(0.2646)\end{array}$ & $\begin{array}{r}1.1513 \\
(0.5623)\end{array}$ \\
\hline Philippines & $\begin{array}{l}0.0127 \\
(0.539)\end{array}$ & $\begin{array}{l}0.4229 \\
(2.304)\end{array}$ & $\begin{array}{l}0.2905 \\
(2.375)\end{array}$ & $\begin{array}{l}-0.0169 \\
(-0.152)\end{array}$ & 0.1920 & $\begin{array}{r}4.0840 \\
(0.0520)\end{array}$ & $\begin{array}{r}3.4481 \\
(0.0448)\end{array}$ & $\begin{array}{r}0.0335 \\
(0.8558)\end{array}$ & $\begin{array}{r}2.3102 \\
(0.3150)\end{array}$ \\
\hline Ghana & $\begin{array}{r}0.0211 \\
(1.732)\end{array}$ & $\begin{array}{l}0.2351 \\
(1.639)\end{array}$ & $\begin{array}{c}0.1825 \\
(1.893)\end{array}$ & $\begin{array}{l}-0.1803 \\
(-1.502)\end{array}$ & 0.1568 & $\begin{array}{r}0.0289 \\
(0.8660)\end{array}$ & $\begin{array}{r}2.8327 \\
(0.0746)\end{array}$ & $\begin{array}{r}8.6603 \\
(0.0059)\end{array}$ & $\begin{array}{r}1.8317 \\
(0.4001)\end{array}$ \\
\hline Guatemala & $\begin{array}{c}0.0216 \\
(1.269)\end{array}$ & $\begin{array}{l}0.2277 \\
(0.994)\end{array}$ & $\begin{array}{l}0.4549 \\
(3.374)\end{array}$ & $\begin{array}{l}-0.0599 \\
(-0.441)\end{array}$ & 0.2107 & $\begin{array}{r}0.3964 \\
(0.5335)\end{array}$ & $\begin{array}{r}0.5512 \\
(0.5819)\end{array}$ & $\begin{array}{r}1.4846 \\
(0.2316)\end{array}$ & $\begin{array}{r}4.4645 \\
(0.1073)\end{array}$ \\
\hline Honduras & $\begin{array}{r}0.0015 \\
(0.0830\end{array}$ & $\begin{array}{l}0.7040 \\
(4.063)\end{array}$ & $\begin{array}{l}0.4774 \\
(3.339)\end{array}$ & $\begin{array}{l}0.1281 \\
(1.144)\end{array}$ & 0.3706 & $\begin{array}{r}1.6300 \\
(0.2111)\end{array}$ & $\begin{array}{r}4.6061 \\
(0.0180)\end{array}$ & $\begin{array}{r}0.1164 \\
(0.7351)\end{array}$ & $\begin{array}{r}6.8968 \\
(0.0317)\end{array}$ \\
\hline Hong Kong & $\begin{array}{l}0.0084 \\
(0.482)\end{array}$ & $\begin{array}{l}0.0797 \\
(0.544)\end{array}$ & $\begin{array}{l}0.2595 \\
(2.562)\end{array}$ & $\begin{array}{l}-0.0554 \\
(-0.859)\end{array}$ & 0.1000 & $\begin{array}{r}2.8111 \\
(0.1036)\end{array}$ & $\begin{array}{r}1.3732 \\
(0.2687)\end{array}$ & $\begin{array}{r}4.0213 \\
(0.0531)\end{array}$ & $\begin{array}{r}0.7885 \\
(0.6742)\end{array}$ \\
\hline India & $\begin{array}{l}-0.0019 \\
(-0.224)\end{array}$ & $\begin{array}{l}1.0037 \\
(9.347)\end{array}$ & $\begin{array}{l}0.2738 \\
(2.311)\end{array}$ & $\begin{array}{r}0.03707 \\
(0.819)\end{array}$ & 0.7211 & $\begin{array}{r}1.1892 \\
(0.2838)\end{array}$ & $\begin{array}{r}0.6888 \\
(0.5099)\end{array}$ & $\begin{array}{r}0.2056 \\
(0.6532)\end{array}$ & $\begin{array}{r}1.7997 \\
(0.4066)\end{array}$ \\
\hline Indonesia & $\begin{array}{l}0.0230 \\
(2.207)\end{array}$ & $\begin{array}{l}0.3741 \\
(3.655)\end{array}$ & $\begin{array}{l}0.3707 \\
(2.542)\end{array}$ & $\begin{array}{r}-0.1125 \\
(-2.183)\end{array}$ & 0.2647 & $\begin{array}{r}0.4177 \\
(0.5228)\end{array}$ & $\begin{array}{r}2.2401 \\
(0.1239)\end{array}$ & $\begin{array}{r}0.4599 \\
(0.5023)\end{array}$ & $\begin{array}{r}8.2016 \\
(0.0166)\end{array}$ \\
\hline Israel & $\begin{array}{l}0.0382 \\
(1.323)\end{array}$ & $\begin{array}{l}0.1131 \\
(0.968)\end{array}$ & $\begin{array}{l}0.2171 \\
(1.923)\end{array}$ & $\begin{array}{l}-0.1174 \\
(-0.828)\end{array}$ & 0.1000 & $\begin{array}{r}1.1003 \\
(0.3023)\end{array}$ & $\begin{array}{r}1.3072 \\
(0.2855)\end{array}$ & $\begin{array}{r}0.2040 \\
(0.6544)\end{array}$ & $\begin{array}{r}4.5323 \\
(0.1037)\end{array}$ \\
\hline Jamaica & $\begin{array}{l}0.0407 \\
(2.123)\end{array}$ & $\begin{array}{l}0.2175 \\
(1.769)\end{array}$ & $\begin{array}{l}0.4589 \\
(3.829)\end{array}$ & $\begin{array}{l}-0.0876 \\
(-1.252)\end{array}$ & 0.2844 & $\begin{array}{r}0.4953 \\
(0.4868)\end{array}$ & $\begin{array}{r}0.3669 \\
(0.6959)\end{array}$ & $\begin{array}{r}0.1853 \\
(0.6696)\end{array}$ & $\begin{array}{r}2.0258 \\
(0.3631)\end{array}$ \\
\hline Malawi & $\begin{array}{l}0.0847 \\
(3.414)\end{array}$ & $\begin{array}{l}0.4564 \\
(2.473)\end{array}$ & $\begin{array}{l}0.6198 \\
(3.852)\end{array}$ & $\begin{array}{l}-0.1732 \\
(-1.577)\end{array}$ & 0.3469 & $\begin{array}{r}0.0236 \\
(0.8788)\end{array}$ & $\begin{array}{r}0.0478 \\
(0.9534)\end{array}$ & $\begin{array}{r}1.0549 \\
(0.3118)\end{array}$ & $\begin{array}{r}2.7386 \\
(0.2543)\end{array}$ \\
\hline Nigeria & $\begin{array}{l}0.0526 \\
(2.837)\end{array}$ & $\begin{array}{l}0.1897 \\
(1.448)\end{array}$ & $\begin{array}{l}0.6163 \\
(3.995)\end{array}$ & $\begin{array}{l}-0.2822 \\
(-2.866)\end{array}$ & 0.2805 & $\begin{array}{r}3.0266 \\
(0.0918)\end{array}$ & $\begin{array}{r}2.1864 \\
(0.1298)\end{array}$ & $\begin{array}{r}1.9299 \\
(0.1740)\end{array}$ & $\begin{array}{r}0.5033 \\
(0.7775)\end{array}$ \\
\hline Pakistan & $\begin{array}{l}0.0682 \\
(3.611)\end{array}$ & $\begin{array}{l}0.3251 \\
(2.609)\end{array}$ & $\begin{array}{l}0.3967 \\
(3.242)\end{array}$ & $\begin{array}{l}-0.3641 \\
(-3.360)\end{array}$ & 0.3492 & $\begin{array}{r}0.3188 \\
(0.5763)\end{array}$ & $\begin{array}{r}0.2214 \\
(0.8026)\end{array}$ & $\begin{array}{r}0.0626 \\
(0.8040)\end{array}$ & $\begin{array}{r}7.4314 \\
(0.0243)\end{array}$ \\
\hline Paraguay & $\begin{array}{l}0.0002 \\
(0.015)\end{array}$ & $\begin{array}{l}0.3199 \\
(2.759)\end{array}$ & $\begin{array}{l}0.3211 \\
(2.978)\end{array}$ & $\begin{array}{l}0.0809 \\
(0.928)\end{array}$ & 0.2705 & $\begin{array}{r}3.2802 \\
(0.0798)\end{array}$ & $\begin{array}{r}3.4894 \\
(0.0434)\end{array}$ & $\begin{array}{r}0.0957 \\
(0.7590)\end{array}$ & $\begin{array}{r}0.1857 \\
(0.9113)\end{array}$ \\
\hline Senegal & $\begin{array}{l}0.0243 \\
(2.133)\end{array}$ & $\begin{array}{l}0.2379 \\
(3.305)\end{array}$ & $\begin{array}{l}0.2367 \\
(2.582)\end{array}$ & $\begin{array}{l}-0.0856 \\
(-1.014)\end{array}$ & 0.2940 & $\begin{array}{r}0.9330 \\
(0.3415)\end{array}$ & $\begin{array}{r}1.6131 \\
(0.2160)\end{array}$ & $\begin{array}{r}1.0868 \\
(0.3047)\end{array}$ & $\begin{array}{r}1.1344 \\
(0.5671)\end{array}$ \\
\hline Thailand & $\begin{array}{l}0.0001 \\
(0.010)\end{array}$ & $\begin{array}{l}0.5938 \\
(3.227)\end{array}$ & $\begin{array}{l}0.5235 \\
(3.764)\end{array}$ & $\begin{array}{r}-0.0188 \\
(1.582)\end{array}$ & 0.3717 & $\begin{array}{r}0.0562 \\
(0.8141)\end{array}$ & $\begin{array}{r}0.1309 \\
(0.8778)\end{array}$ & $\begin{array}{r}0.0000 \\
(0.9992)\end{array}$ & $\begin{array}{r}0.0649 \\
(0.9680)\end{array}$ \\
\hline Venezuela & $\begin{array}{l}-0.0218 \\
(-0.564)\end{array}$ & $\begin{array}{l}-0.1354 \\
(-0.662)\end{array}$ & $\begin{array}{l}0.4410 \\
(3.638)\end{array}$ & $\begin{array}{l}-0.2824 \\
(-0.147)\end{array}$ & 0.2760 & $\begin{array}{r}0.1072 \\
(0.7455)\end{array}$ & $\begin{array}{r}0.9454 \\
(0.3997)\end{array}$ & $\begin{array}{r}0.2246 \\
(0.6386)\end{array}$ & $\begin{array}{r}0.6811 \\
(0.7113)\end{array}$ \\
\hline
\end{tabular}

Notes: $\mathrm{t}$ statistic in parentheses.

$\bar{R}^{2}: R^{2}$ adjusted; LM (i): Lagrange multiplier test for serial correlation of order i (p-value in parentheses); ARCH: first-order test for conditional autoregressive heteroskedasticity ( $\mathrm{p}$-value in parentheses); JB: Jarque-Bera statistic for normality ( $\mathrm{p}$-value in parentheses). 


\section{COMPARISON AMONG THE APPROACHES}

We compare four approaches concerning the long-run behavior of saving and investment: the error correction model (ECM), the Dickey-Fuller test for current account stationarity and the cointegration tests of Engle-Granger and Johansen. The results are summarized in Table 4.

Table 4 - Long-run behavior of saving and investment

\begin{tabular}{llllll}
\hline Country & $t_{E C M}$ & Engle Granger & $\begin{array}{c}\text { Current account } \\
\text { ADF }\end{array}$ & Johansen trace & Johansen max \\
\hline Argentina & 2.147 & -3.029 & $-2.835^{* *}$ & No Cointegration & No Cointegration \\
Brazil & 2.015 & -2.126 & $-1.967^{*}$ & No Cointegration & No Cointegration \\
Chile & $3.797^{*}$ & -2.129 & $-3.347^{* *}$ & Cointegration & No Cointegration \\
Colombia & 1.633 & $-4.308^{*}$ & $-2.390^{*}$ & Cointegration & Cointegration \\
S. Korea & 1.743 & -2.132 & -1.613 & Cointegration & Cointegration \\
Ecuador & 2.086 & -2.188 & -1.832 & No Cointegration & No Cointegration \\
Philippines & 2.409 & -2.773 & -1.384 & No Cointegration & No Cointegration \\
Ghana & 1.464 & -1.915 & -0.317 & No Cointegration & No Cointegration \\
Guatemala & $3.420^{*}$ & -3.145 & -0.964 & No Cointegration & No Cointegration \\
Honduras & $3.147^{*}$ & -3.179 & -0.446 & Cointegration & Cointegration \\
Hong Kong & 2.438 & -2.317 & -1.832 & No Cointegration & No Cointegration \\
India & 2.272 & $-3.409^{*}$ & -0.690 & No Cointegration & No Cointegration \\
Indonesia & 1.279 & -3.165 & $-2.542^{*}$ & Cointegration & Cointegration \\
Israel & 2.298 & -1.569 & -0.893 & No Cointegration & No Cointegration \\
Jamaica & $3.593^{*}$ & -3.163 & -1.769 & No Cointegration & No Cointegration \\
Malawi & $3.448^{*}$ & -2.188 & -0.917 & No Cointegration & No Cointegration \\
Nigeria & 2.523 & -1.847 & -1.438 & Cointegration & Cointegration \\
Pakistan & 1.087 & $-3.285^{*}$ & -0.738 & No Cointegration & No Cointegration \\
Paraguay & $2.878^{*}$ & -2.619 & -0.044 & Cointegration & Cointegration \\
Senegal & $2.711^{*}$ & -2.441 & -0.673 & No Cointegration & No Cointegration \\
Thailand & $3.359^{*}$ & -2.743 & -0.496 & Cointegration & Cointegration \\
Venezuela & $3.851^{*}$ & -2.455 & -1.890 & Cointegration & Cointegration \\
\hline
\end{tabular}

Notes: For the statistic $t_{E C M}$ the critical value is 2.57 .

For the ADF statistic, the critical values at the $5 \%$ and $1 \%$ levels of significance are, respectively, -1.95 and -2.58 .

For the Engle-Granger test, the critical value at the $5 \%$ level of significance is -3.24 .

The Dickey-Fuller regressions for the current account do not include a constant and trend. The number of lags is chosen based on the significance of the highest lag.

* and ${ }^{* *}$ mean significance at the $5 \%$ and $1 \%$ levels, respectively.

The error correction model indeed points to cointegration for a greater number of countries than does the Engle-Granger test, but not more than the Johansen test. Nevertheless, the countries where cointegration is found do not always coincide. In fact, it is difficult to establish whether or not there is capital mobility based on the unit root/cointegration approaches.

Regarding the sort-run correlation, Table 5 summarizes the estimates of $\beta$ for the error correction model and for two special cases of this model, the static equation and the equation in first differences.

The static equation in general results in estimates of the sort-run coefficient greater than those obtained with the error correction model. ${ }^{4}$ The mean estimate is 0.64 while the mean estimate of

4 There is autocorrelation in the error terms in many of the estimates from the static model that introduce bias in the sample variances and make the estimates inefficient. The literature is not concerned with discussing the diagnostic tests of this formulation, limiting itself to reporting the estimates of the correlation coefficient and analyzing it. 
the error correction model is 0.42 . The estimates obtained using the equation in differences $(0.34)$, however, are quite similar to those obtained with the error correction model.

Table 5 - Short-run correlation estimates

\begin{tabular}{|c|c|c|c|}
\hline Country & Error correction & Static & Differences \\
\hline \multirow[t]{2}{*}{ Argentina } & 0.6444 & 0.8267 & 0.5634 \\
\hline & $(6.278)$ & $(10.074)$ & $(5.612)$ \\
\hline \multirow[t]{2}{*}{ Brazil } & 0.6316 & 0.4376 & 0.6177 \\
\hline & (6.327) & (2.966) & (5.941) \\
\hline \multirow[t]{2}{*}{ Chile } & 0.6449 & 0.6731 & 0.6359 \\
\hline & $(6.882)$ & $(9.984)$ & (5.749) \\
\hline \multirow[t]{2}{*}{ Colombia } & 0.2250 & 0.0006 & 0.1556 \\
\hline & $(1.376)$ & $(0.005)$ & $(0.962)$ \\
\hline \multirow[t]{2}{*}{ S. Korea } & 0.5466 & 0.5999 & 0.5281 \\
\hline & $(2.781)$ & (12.663) & $(2.613)$ \\
\hline \multirow[t]{2}{*}{ Ecuador } & -0.0928 & 0.4937 & -0.2249 \\
\hline & $(-0.559)$ & (5.093) & $(-1.399)$ \\
\hline \multirow[t]{2}{*}{ Philippines } & 0.4304 & 0.8952 & 0.4205 \\
\hline & $(2.472)$ & $(5.916)$ & (2.261) \\
\hline \multirow[t]{2}{*}{ Ghana } & 0.3283 & 0.5629 & 0.2808 \\
\hline & (2.493) & (3.124) & (2.164) \\
\hline \multirow[t]{2}{*}{ Guatemala } & 0.2546 & 0.7210 & 0.1883 \\
\hline & $(1.167)$ & (4.635) & $(0.756)$ \\
\hline \multirow[t]{2}{*}{ Honduras } & 0.6598 & 1.1328 & 0.5868 \\
\hline & (3.888) & (9.596) & (3.108) \\
\hline \multirow[t]{2}{*}{ Hong Kong } & 0.1146 & 0.7234 & 0.0439 \\
\hline & $(0.816)$ & (7.622) & (0.299) \\
\hline \multirow[t]{2}{*}{ India } & 0.9840 & 1.0331 & 0.9799 \\
\hline & $(9.450)$ & (17.093) & (8.884) \\
\hline \multirow[t]{2}{*}{ Indonesia } & 0.3302 & 0.7191 & 0.2772 \\
\hline & (3.117) & (17.360) & (2.817) \\
\hline \multirow[t]{2}{*}{ Israel } & 0.1511 & 0.0020 & 0.1010 \\
\hline & (1.443) & $(0.018)$ & $(0.930)$ \\
\hline \multirow[t]{2}{*}{ Jamaica } & 0.2538 & 0.7444 & 0.1747 \\
\hline & (2.105) & (8.399) & (1.268) \\
\hline \multirow[t]{2}{*}{ Malawi } & 0.5452 & 0.6748 & 0.4487 \\
\hline & (1.587) & (3.330) & (1.281) \\
\hline \multirow[t]{2}{*}{ Nigeria } & 0.2243 & 0.5028 & 0.1009 \\
\hline & $(1.557)$ & (7.143) & (0.692) \\
\hline \multirow[t]{2}{*}{ Pakistan } & 0.3968 & 0.3513 & 0.3745 \\
\hline & (2.822) & (3.549) & (2.604) \\
\hline \multirow[t]{2}{*}{ Paraguay } & 0.2741 & 0.9816 & 0.1618 \\
\hline & $(2.618)$ & (7.2819) & (1.511) \\
\hline \multirow[t]{2}{*}{ Senegal } & 0.2566 & 0.3312 & 0.2020 \\
\hline & (3.685) & $(3.442)$ & $(2.782)$ \\
\hline \multirow[t]{2}{*}{ Thailand } & 0.5489 & 1.1308 & 0.5574 \\
\hline & (2.953) & (19.455) & $(2.628)$ \\
\hline \multirow[t]{2}{*}{ Venezuela } & -0.1278 & 0.6368 & -0.2698 \\
\hline & $(-0.656)$ & $(3.861)$ & $(-1.188)$ \\
\hline
\end{tabular}

Note: $\mathrm{t}$ statistic in parentheses.

Finally, Table 6 summarizes the results regarding capital mobility. If $\beta$ is not significantly different from zero, there is capital mobility; if $\beta$ is not significantly different from one, capital is immobile; and if $\beta$ is significantly different from zero and one, there is an intermediate degree of capital mobility. 
Table 6 - Capital mobility

\begin{tabular}{|c|c|c|c|}
\hline Country & Error correction & Static & Differences \\
\hline \multirow[t]{4}{*}{ Argentina } & 0.6444 & 0.8267 & 0.5634 \\
\hline & $(6.278)$ & $(10.074)$ & $(5.612)$ \\
\hline & {$[-3.464]$} & [-2.112] & [-4.349] \\
\hline & Intermediate & Intermediate & Intermediate \\
\hline \multirow[t]{4}{*}{ Brazil } & 0.6316 & 0.4376 & 0.6177 \\
\hline & $(6.327)$ & $(2.966)$ & $(5.941)$ \\
\hline & {$[-3.691]$} & [-3.812] & {$[-3.678]$} \\
\hline & Intermediate & Intermediate & Intermediate \\
\hline \multirow[t]{4}{*}{ Chile } & 0.6449 & 0.6731 & 0.6359 \\
\hline & $(6.882)$ & $(9.984)$ & $(5.749)$ \\
\hline & [-3.789] & [-4.849] & [-3.290] \\
\hline & Intermediate & Intermediate & Intermediate \\
\hline \multirow[t]{4}{*}{ Colombia } & 0.2250 & 0.0006 & 0.1556 \\
\hline & (1.376) & $(0.005)$ & $(0.962)$ \\
\hline & {$[-4.739]$} & {$[-8.412]$} & {$[-5.222]$} \\
\hline & Mobility & Mobility & Mobility \\
\hline \multirow[t]{4}{*}{ S. Korea } & 0.5466 & 0.5999 & 0.5281 \\
\hline & (2.781) & (12.663) & $(2.613)$ \\
\hline & {$[-2.307]$} & [-8.447] & [-2.335] \\
\hline & Intermediate & Intermediate & Intermediate \\
\hline \multirow[t]{4}{*}{ Ecuador } & -0.0928 & 0.4937 & -0.2249 \\
\hline & $(-0.559)$ & $(5.093)$ & $(-1.399)$ \\
\hline & {$[-6.584]$} & {$[-5.223]$} & {$[-7.618]$} \\
\hline & Mobility & Intermediate & Mobility \\
\hline \multirow[t]{4}{*}{ Philippines } & 0.4304 & 0.8952 & 0.4205 \\
\hline & (2.472) & $(5.916)$ & $(2.261)$ \\
\hline & {$[-3.271]$} & {$[-0.692]$} & [-3.116] \\
\hline & Intermediate & Immobility & Intermediate \\
\hline \multirow[t]{4}{*}{ Ghana } & 0.3283 & 0.5629 & 0.2808 \\
\hline & (2.493) & (3.124) & $(2.164)$ \\
\hline & {$[-5.101]$} & {$[-2.426]$} & {$[-5.543]$} \\
\hline & Intermediate & Intermediate & Intermediate \\
\hline \multirow[t]{4}{*}{ Guatemala } & 0.2546 & 0.7210 & 0.1883 \\
\hline & $(1.167)$ & (4.635) & $(0.756)$ \\
\hline & {$[-3.417]$} & [-1.794] & {$[-3.258]$} \\
\hline & Mobility & Immobility & Mobility \\
\hline \multirow[t]{4}{*}{ Honduras } & 0.6598 & 1.1328 & 0.5868 \\
\hline & (3.888) & (9.596) & (3.108) \\
\hline & {$[-2.005]$} & [1.125] & [-2.188] \\
\hline & Intermediate & Immobility & Intermediate \\
\hline \multirow[t]{4}{*}{ Hong Kong } & 0.1146 & 0.7234 & 0.0439 \\
\hline & $(0.816)$ & (7.622) & $(0.299)$ \\
\hline & {$[-6.305]$} & {$[-2.930]$} & {$[-6.501]$} \\
\hline & Mobility & Intermediate & Mobility \\
\hline \multirow[t]{4}{*}{ India } & 0.9840 & 1.0331 & 0.9799 \\
\hline & $(9.450)$ & (17.093) & $(8.884)$ \\
\hline & {$[-0.1534]$} & [0.547] & {$[-0.182]$} \\
\hline & Immobility & Immobility & Immobility \\
\hline \multirow[t]{4}{*}{ Indonesia } & 0.3302 & 0.7191 & 0.2772 \\
\hline & $(3.117)$ & $(17.360)$ & $(2.817)$ \\
\hline & [-6.322] & {$[-6.782]$} & [-7.344] \\
\hline & Intermediate & Intermediate & Intermediate \\
\hline \multirow[t]{4}{*}{ Israel } & 0.1511 & 0.0020 & 0.1010 \\
\hline & (1.443) & $(0.018)$ & $(0.930)$ \\
\hline & {$[-8.111]$} & {$[-9.263]$} & {$[-8.276]$} \\
\hline & Mobility & Mobility & Mobility \\
\hline
\end{tabular}




\begin{tabular}{|c|c|c|c|}
\hline Country & Error correction & Static & Differences \\
\hline \multirow[t]{4}{*}{ Jamaica } & 0.2538 & 0.7444 & 0.1747 \\
\hline & (2.105) & (8.399) & (1.268) \\
\hline & {$[-6.189]$} & [-2.885] & [-5.991] \\
\hline & Intermediate & Intermediate & Mobility \\
\hline \multirow[t]{4}{*}{ Malawi } & 0.5452 & 0.6748 & 0.4487 \\
\hline & (3.035) & (6.968) & (2.201) \\
\hline & {$[-2.532]$} & {$[-3.358]$} & {$[-2.704]$} \\
\hline & Intermediate & Immobility & Intermediate \\
\hline \multirow[t]{4}{*}{ Nigeria } & 0.2243 & 0.5028 & 0.1009 \\
\hline & (1.557) & (7.143) & $(0.692)$ \\
\hline & {$[-5.386]$} & {$[-7.065]$} & {$[-6.168]$} \\
\hline & Mobility & Intermediate & Mobility \\
\hline \multirow[t]{4}{*}{ Pakistan } & 0.3968 & 0.3513 & 0.3745 \\
\hline & $(2.822)$ & (3.549) & (2.604) \\
\hline & {$[-4.290]$} & {$[-6.554]$} & [-4.889] \\
\hline & Intermediate & Intermediate & Intermediate \\
\hline \multirow[t]{4}{*}{ Paraguay } & 0.2741 & 0.9816 & 0.1618 \\
\hline & (2.618) & $(7.2819)$ & (1.511) \\
\hline & {$[-6.931]$} & {$[-0.137]$} & {$[-7.828]$} \\
\hline & Intermediate & Immobility & Mobility \\
\hline \multirow[t]{4}{*}{ Senegal } & 0.2566 & 0.3312 & 0.2020 \\
\hline & (3.685) & (3.442) & $(2.782)$ \\
\hline & {$[-10.675]$} & {$[-6.951]$} & {$[-10.989]$} \\
\hline & Intermediate & Intermediate & Intermediate \\
\hline \multirow[t]{4}{*}{ Thailand } & 0.5489 & 1.1308 & 0.5574 \\
\hline & (2.953) & (19.455) & (2.628) \\
\hline & {$[-2.427]$} & [2.250] & {$[-2.087]$} \\
\hline & Intermediate & Intermediate & Intermediate \\
\hline \multirow[t]{4}{*}{ Venezuela } & -0.1278 & 0.6368 & -0.2698 \\
\hline & $(-0.656)$ & (3.861) & $(-1.188)$ \\
\hline & {$[-5.787]$} & {$[-2.202]$} & {$[-5.594]$} \\
\hline & Mobility & Intermediate & Mobility \\
\hline
\end{tabular}

Note: $\mathrm{t}$ statistics in parentheses for $\beta=0$, and brackets for $\beta=1$.

Except for Jamaica and Pakistan, the results of the error correction model and the equation in differences are equal. For Paraguay, the three approaches lead to different results. For Ecuador, Philippines, Guatemala, Honduras, Hong Kong, Malawi, Nigeria and Venezuela the static model implies different results from the error correction model and the model in first differences. For Jamaica, the error correction model and the static model also present the same result.

\section{STRUCTURAL CHANGES}

Given the belief that over time many countries have reduced their capital controls, one would expect a smaller correlation between saving and investment for more recent periods. To test the stability of the saving-investment relation, we estimate the following equation:

$$
\Delta i_{t}=\alpha+\left(\beta_{1} D_{1}+\beta_{2} D_{2}\right) \Delta s_{t}+\gamma\left(s_{t-1}-i_{t-1}\right)+\varepsilon_{t}
$$

where $D_{i}(i=1,2)$ denote dummies, which are 1 during the sub-interval $\mathrm{i}$ and 0 otherwise, and again $i=I / Y$ and $s=S / Y$. Thus, equation (5.1) is estimated with short-run coefficients varying with time. We specify two regimes: $1960-74$ and $1975-96$. We chose 1974 as a breakpoint because 
the literature indicates that there was a generalized trend towards greater capital mobility starting in the mid-1970s. Table 7 reports the results of the estimations. All the diagnostic tests are met.

Table 7 - Results of the estimation of the error correction model with structural changes

\begin{tabular}{|c|c|c|c|c|}
\hline Country & Constant & $D_{(60-75)} \Delta s_{t}$ & $D_{(75-96)} \Delta s_{t}$ & $s_{t-1}-i_{t-1}$ \\
\hline Argentina & $\begin{array}{l}-0.0038 \\
(-1.153)\end{array}$ & $\begin{array}{l}0.6304 \\
(4.775)\end{array}$ & $\begin{array}{l}0.6661 \\
(4.094)\end{array}$ & $\begin{array}{l}0.2999 \\
(2.053)\end{array}$ \\
\hline Brazil & $\begin{array}{l}-0.0005 \\
(-0.227)\end{array}$ & $\begin{array}{l}0.6072 \\
(3.830)\end{array}$ & $\begin{array}{l}0.6484 \\
(4.932)\end{array}$ & $\begin{array}{l}0.1820 \\
(1.978)\end{array}$ \\
\hline Chile & $\begin{array}{r}0.000402 \\
(0.108)\end{array}$ & $\begin{array}{l}0.8495 \\
(7.019)\end{array}$ & $\begin{array}{r}0.42165 \\
(3.335)\end{array}$ & $\begin{array}{l}0.4893 \\
(4.219)\end{array}$ \\
\hline Colombia & $\begin{array}{l}-0.0001 \\
(-0.048)\end{array}$ & $\begin{array}{l}0.3443 \\
(1.144)\end{array}$ & $\begin{array}{l}0.1761 \\
(0.903)\end{array}$ & $\begin{array}{l}0.1653 \\
(1.586)\end{array}$ \\
\hline S. Korea & $\begin{array}{l}0.0108 \\
(1.973)\end{array}$ & $\begin{array}{l}1.0348 \\
(4.238)\end{array}$ & $\begin{array}{l}0.0299 \\
(0.119)\end{array}$ & $\begin{array}{l}0.2062 \\
(2.654)\end{array}$ \\
\hline Ecuador & $\begin{array}{l}0.0017 \\
(0.399)\end{array}$ & $\begin{array}{l}0.1702 \\
(0.645)\end{array}$ & $\begin{array}{l}-0.2514 \\
(-1.219)\end{array}$ & $\begin{array}{l}0.2096 \\
(1.877)\end{array}$ \\
\hline Philippines & $\begin{array}{l}0.0106 \\
(2.325)\end{array}$ & $\begin{array}{l}0.0714 \\
(0.316)\end{array}$ & $\begin{array}{l}0.8574 \\
(3.477)\end{array}$ & $\begin{array}{l}0.2619 \\
(2.299)\end{array}$ \\
\hline Ghana & $\begin{array}{l}0.0054 \\
(0.964)\end{array}$ & $\begin{array}{l}0.0661 \\
(0.357)\end{array}$ & $\begin{array}{l}0.5474 \\
(3.224)\end{array}$ & $\begin{array}{l}0.1585 \\
(1.758)\end{array}$ \\
\hline Guatemala & $\begin{array}{l}0.0108 \\
(2.035)\end{array}$ & $\begin{array}{r}0.8322 \\
(2.35)\end{array}$ & $\begin{array}{l}-0.0929 \\
(-0.344)\end{array}$ & $\begin{array}{l}0.3831 \\
(3.043)\end{array}$ \\
\hline Honduras & $\begin{array}{l}0.0217 \\
(3.400)\end{array}$ & $\begin{array}{l}-0.3492 \\
(-1.080)\end{array}$ & $\begin{array}{l}0.9168 \\
(5.595)\end{array}$ & $\begin{array}{l}0.4724 \\
(3.898)\end{array}$ \\
\hline Hong Kong & $\begin{array}{l}-0.0044 \\
(-0.026)\end{array}$ & $\begin{array}{l}-0.0262 \\
(-0.132)\end{array}$ & $\begin{array}{r}0.25523 \\
(1.284)\end{array}$ & $\begin{array}{l}0.2061 \\
(2.227)\end{array}$ \\
\hline India & $\begin{array}{l}0.0053 \\
(1.942)\end{array}$ & $\begin{array}{l}0.8782 \\
(3.354)\end{array}$ & $\begin{array}{r}1.004 \\
(8.727)\end{array}$ & $\begin{array}{l}0.2832 \\
(2.276)\end{array}$ \\
\hline Indonesia & $\begin{array}{l}0.0021 \\
(0.572)\end{array}$ & $\begin{array}{l}0.5070 \\
(4.806)\end{array}$ & $\begin{array}{r}-0.1266 \\
(0.782)\end{array}$ & $\begin{array}{l}0.1061 \\
(1.237)\end{array}$ \\
\hline Israel & $\begin{array}{l}0.0153 \\
(2.047)\end{array}$ & $\begin{array}{l}0.1699 \\
(1.474)\end{array}$ & $\begin{array}{l}0.0506 \\
(0.192)\end{array}$ & $\begin{array}{l}0.1376 \\
(2.261)\end{array}$ \\
\hline Jamaica & $\begin{array}{l}0.0189 \\
(2.654)\end{array}$ & $\begin{array}{l}0.5671 \\
(3.232)\end{array}$ & $\begin{array}{l}0.0345 \\
(0.235)\end{array}$ & $\begin{array}{l}0.3767 \\
(3.571)\end{array}$ \\
\hline Malawi & $\begin{array}{l}0.0571 \\
(3.195)\end{array}$ & $\begin{array}{l}1.0346 \\
(2.955)\end{array}$ & $\begin{array}{l}0.3816 \\
(1.884)\end{array}$ & $\begin{array}{l}0.5245 \\
(3.678)\end{array}$ \\
\hline Nigeria & $\begin{array}{l}0.0004 \\
(0.055)\end{array}$ & $\begin{array}{l}0.4560 \\
(1.106)\end{array}$ & $\begin{array}{l}0.1965 \\
(1.288)\end{array}$ & $\begin{array}{l}0.2987 \\
(2.545)\end{array}$ \\
\hline Pakistan & $\begin{array}{l}0.0077 \\
(1.053)\end{array}$ & $\begin{array}{l}0.6755 \\
(3.726)\end{array}$ & $\begin{array}{l}0.1079 \\
(0.585)\end{array}$ & $\begin{array}{l}0.0849 \\
(0.895)\end{array}$ \\
\hline Paraguay & $\begin{array}{l}0.0116 \\
(2.283)\end{array}$ & $\begin{array}{l}0.5925 \\
(3.035)\end{array}$ & $\begin{array}{l}0.1614 \\
(1.381)\end{array}$ & $\begin{array}{l}0.2690 \\
(2.580)\end{array}$ \\
\hline Senegal & $\begin{array}{l}0.0138 \\
(2.706)\end{array}$ & $\begin{array}{l}0.2378 \\
(2.015)\end{array}$ & $\begin{array}{l}0.2663 \\
(3.107)\end{array}$ & $\begin{array}{l}0.1665 \\
(2.615)\end{array}$ \\
\hline Thailand & $\begin{array}{l}0.0177 \\
(3.098)\end{array}$ & $\begin{array}{l}0.7039 \\
(2.559)\end{array}$ & $\begin{array}{l}0.4213 \\
(1.685)\end{array}$ & $\begin{array}{l}0.4227 \\
(3.016)\end{array}$ \\
\hline Venezuela & $\begin{array}{l}-0.0269 \\
(-2.567)\end{array}$ & $\begin{array}{l}-0.2546 \\
(-0.570)\end{array}$ & $\begin{array}{l}-0.0934 \\
(-0.414)\end{array}$ & $\begin{array}{l}0.4404 \\
(3.805)\end{array}$ \\
\hline
\end{tabular}

Note: $\mathrm{t}$ statistic in parentheses.

The hypothesis that the correlation coefficient is constant is rejected for Argentina, Chile, S. Korea, Philippines, Guatemala, Honduras, Indonesia, Jamaica and Pakistan. For the remaining countries, the correlation coefficient appears to be quite stable. For those countries where the coefficients did not seem statistically different between the two periods, other possible structural 
change periods were tested. For Brazil, for example, we establish different regimes for 1960-1989 and 1990-96 (since economic opening really only got under way in 1990) but this hypothesis was also rejected. For all countries except Argentina, Brazil, Philippines, Ghana, Honduras, Hong Kong, India, Senegal and Venezuela, the saving-investment correlation is smaller in the second sub-interval. These changes are consistent with greater capital mobility.

Table 8 - Tests of significance of structural changes

\begin{tabular}{lrc}
\hline Country & F statistic & p-value \\
\hline Argentina & 20.872 & $0.000^{*}$ \\
Brazil & 0.040 & 0.843 \\
Chile & 5.072 & $0.031^{*}$ \\
Colombia & 0.225 & 0.639 \\
S. Korea & 8.478 & $0.007^{*}$ \\
Ecuador & 1.625 & 0.212 \\
Philippines & 5.358 & $0.027^{*}$ \\
Ghana & 3.744 & 0.062 \\
Guatemala & 4.079 & $0.052^{*}$ \\
Honduras & 12.261 & $0.001^{*}$ \\
Hong Kong & 1.006 & 0.323 \\
India & 0.195 & 0.662 \\
Indonesia & 11.747 & $0.002^{*}$ \\
Israel & 0.174 & 0.679 \\
Jamaica & 5.462 & $0.026^{*}$ \\
Malawi & 2.609 & 0.116 \\
Nigeria & 0.361 & 0.552 \\
Pakistan & 4.249 & $0.047^{*}$ \\
Paraguay & 3.626 & 0.066 \\
Senegal & 0.039 & 0.843 \\
Thailand & 0.590 & 0.448 \\
Venezuela & 0.100 & 0.753 \\
\hline
\end{tabular}

Note: * means that the null hypothesis of constant coefficients is rejected at the $5 \%$ level of significance.

The error correction coefficients $\gamma$ do not substantially change in any of the countries. Again, the relevance of the intertemporal budget constraint is confirmed for Chile, Guatemala, Honduras, Jamaica, Malawi, Paraguay, Senegal, S. Korea, Thailand and Venezuela.

\section{Conclusions}

The purpose of this paper is to verify if the error-correction approach is the best alternative to asses capital mobility in developing countries, as argued by Jansen (1996) and Jansen and Schulze (1996) for developed countries. An error correction model is a synthesis of the other approaches in the literature and is the only one with theoretical backing. We also estimate the equation of Feldstein and Horioka using the variables in levels and in first differences, to evaluate what type of bias these specifications imply.

The results of the cointegration tests are very contradictory. The superiority attributed by Jansen (1996) and Jansen and Schulze (1996) to the error correction model to test for cointegration does not appear to hold for developing countries. Regarding the short-run correlation, the specification in levels generates a considerable upward bias, favoring rejection of the hypothesis of capital 
mobility according to the criterion of Feldstein and Horioka. The specification in differences, on the other hand, does not result in bias. The same result is obtained by Jansen (1996) for developed countries. Jansen (1996) even establishes: "This is a reassuring idea when estimating saving-investment correlations for developing countries, for which often only short time series are available and consequently the long-run relation cannot be reliably estimated. Forgetting about the long run and switching to a specification in differences seems then to be a reasonable strategy." (p. 768). We believe, however, that perhaps it is not a question only of estimating the long-run relation reliably. The long-term coefficient implies solvency. In this way, when $\gamma=0$ is not rejected, i.e., when saving and investment are not cointegrated, the intertemporal budget constraint is simply not met. Evidence in this sense, for developing countries, can be found in Sawada (1995). In this case, the correct specification is indeed the equation in differences.

We agree that in principle an error correction model should be a richer specification than those generally employed to assess capital mobility, but we disagree that it supplies more than one form of doing so, at least for developing countries. As seen before, cointegration between saving and investment or stationarity of the current account indicates solvency. If it is not possible to find evidence of cointegration, then this is indicative that the country does not meet its intertemporal budget constraint instead of evidence of capital mobility. As Jansen (1996) himself contradictorily states, "A lower $\gamma$ implies that a country is able to run for a longer time a deficit or surplus in excess of its long-run value. The intertemporal budget constraint is now less restrictive when a country tries to smooth its aggregate expenditure by borrowing or lending in the world capital market."

Based on the results obtained for developing countries, we can thus conclude that an error correction model in practice does not seem the best choice. Although the theory implies that there is a long-run relationship between saving and investment, this does not seem to be the case for the majority of these economies individually. Therefore, the equation in differences is not poorly specified. Based on this equation, there exists an intermediate degree of capital mobility according to the criterion of Feldstein and Horioka. 


\section{APPENDIX - TESTS OF STATIONARITY OF SAVING AND INVESTMENT}

The results for the augmented Dickey-Fuller (ADF) and Phillips-Perron (PP) tests for investment and saving (expressed as ratios of the product) are shown in Table A. 1.

Table A.1 - Unit root tests: saving and investment

\begin{tabular}{|c|c|c|c|c|}
\hline Country & $\begin{array}{c}\text { Investment } \\
\text { ADF }\end{array}$ & $\begin{array}{c}\text { Saving } \\
\text { ADF }\end{array}$ & $\begin{array}{c}\text { Investment } \\
\text { PP }\end{array}$ & $\begin{array}{c}\text { Saving } \\
\text { PP }\end{array}$ \\
\hline Argentina & -2.059 & -2.285 & -2.228 & -2.391 \\
\hline Brazil & -2.592 & -3.241 & -2.752 & -3.123 \\
\hline Chile & -3.156 & -1.928 & -3.121 & -2.623 \\
\hline Colombia & $-4.109^{*}$ & -3.243 & $-4.115^{\star}$ & -2.691 \\
\hline S. Korea & -2.957 & -1.816 & -3.057 & -1.816 \\
\hline Ecuador & -1.898 & -2.027 & -1.772 & -2.084 \\
\hline Philippines & -1.862 & -1.864 & -2.201 & -1.652 \\
\hline Ghana & -1.108 & -1.866 & -1.767 & -3.937 \\
\hline Guatemala & -2.247 & -1.910 & -2.158 & -1.816 \\
\hline Honduras & -1.260 & -1.585 & -2.159 & -1.789 \\
\hline Hong Kong & -1.497 & -1.828 & -2.070 & -1.565 \\
\hline India & $-4.110^{*}$ & -3.196 & $-4.119^{*}$ & -3.187 \\
\hline Indonesia & -1.300 & -1.918 & -2.361 & -2.088 \\
\hline Israel & -1.487 & -2.304 & -2.479 & -2.391 \\
\hline Jamaica & -1.668 & -2.052 & -1.543 & -2.036 \\
\hline Malawi & -2.479 & -1.938 & -2.349 & -2.015 \\
\hline Nigeria & -2.795 & -2.112 & -2.259 & -2.171 \\
\hline Pakistan & -3.400 & -2.171 & -3.489 & -2.289 \\
\hline Paraguay & -1.460 & -3.017 & -1.709 & -2.979 \\
\hline Senegal & -1.889 & -2.272 & -1.869 & -2.121 \\
\hline Thailand & -2.413 & -2.149 & -2.494 & -2.011 \\
\hline Venezuela & -2.484 & -2.768 & -2.549 & -2.761 \\
\hline
\end{tabular}

Notes: For the ADF statistic. the critical values at the $5 \%$ and $1 \%$ levels of significance are. respectively. -3.53 and -4.20 .

The regressions of the tests include a constant and trend. The number of lags is chosen based on the significance of the highest lag.

* means the null hypothesis is rejected at the $5 \%$ level.

\section{REFERENCES}

Argimón, I.; Roldán, J. M. Saving, investment and international capital mobility in EC countries. European Economic Review, 38, p. 59-67, January 1994.

Bagnai, A.; Manzocchi, S. Unit root tests of capital mobility in the less developed countries. Weltwirtschaftliches Archiv, v.132, n. 3, p. 545-557, 1996.

Baxter, M.; Crucini, M. J. Explaining saving-investment correlations. American Economic Review, v. 83, n. 3, p. 103-115, 1993.

Bayoumi, T. Saving-investment correlations: immobile capital, government policy, or endogenous behavior. IMF Staff Papers, 37, p. 360-387, June 1990.

Dickey, D. A.; Fuller, W. A. Likelihood ratio statistics for autoregressive time series with a unit root. Econometrica, 49, p. 1057-1072, June 1981. 
Dolado, J.; Jenkinson, T.; Sosvilla-Rovera, S. Cointegration and unit roots. Journal of Economic Surveys, 4, p. 249-273, 1990.

Dooley, M.; Frankel, J.; Mathieson, D. International capital mobility: what do saving-investment correlations tell us? IMF Staff Papers, v. 34, n. 3, p. 503-530, 1987.

Engle, R. F.; Granger, C. W. J. Cointegration and error correction: representation, estimation, and testing. Econometrica, 55, p. 251-276, 1987.

Feldstein, M. Domestic saving and international capital movements in the long run and in the short run. European Economic Review, p. 129-151, 1983.

Feldstein, M.; Bacchetta, P. National saving and international investment. In: Bernheim, D.; Shoven, J. (eds.), National saving and economic performance. Chicago: University of Chicago Press, 1991, p. 201-220.

Feldstein, M.; Horioka, C. Domestic saving and international capital flows. Economic Journal, 90, p. $314-$ 329, June 1980.

Finn, M. G. On saving and investment dynamics in a small open economy. Journal of International Economics, 28, p. 1-21, August 1980.

Frankel, J. International capital mobility and crowding-out in the U.S. economy: imperfect integration of financial markets or goods markets? In: Hafer, R. (ed.), How open is the U.S. economy? Lexington: Lexington Books for the Federal Reserve Bank of St. Louis, 1986, p. 33-67.

Quantifying international capital mobility in the 1980s. In: Bernheim, D.; Shoven, J. (eds.), National saving and economic performance. Chicago: Chicago University Press, 1991, p. 227-260.

Granger, C. W. J.; Newbold, P. Spurious regression in econometrics. Journal of Econometrics, v. 2, n. 2, p. 111-120, 1974.

Gundlach, E.; Sinn, E. Unit root tests of the current account balance: implications for international capital mobility. Applied Economics, 24, p. 617-625, June 1992.

Haan, J.; Siermann, C. L. J. Saving, investment and capital mobility: a comment on Leachman (1991). Open Economies Review, 5, p. 5-17, 1994.

Harberger, A. C. Vignettes on the world capital market. American Economic Review, v. 70, Papers and Proceedings, p. 331-337, 1980.

Jansen, W. J. Estimating saving-investment correlations: evidence for OECD countries based on an error correction model. Journal of International Money and Finance, 5, p. 749-781, 1996.

Jansen, W. J.; Schulze, G. G. Theory-based measurement of the saving-investment correlation with an application to Norway. Economic Inquiry, v. XXXIV, p. 116-132, 1996.

Leachman, L. L. Saving, investment and capital mobility among OECD countries. Open Economics Review, v. 2, Issue n. 2, p. 137-163, 1991.

Mamingi, N. Saving-investment correlations and capital mobility: the experience of developing countries. Journal of Policy Modeling, v. 19, n. 6, p. 605-626, 1997.

Miller, S. M. Are saving and investment cointegrated? Economics Letters, 27, p. 31-34, 1988.

Montiel, P. Capital mobility in developing countries: some measurement issues and empirical estimates. World Bank Economic Review, v. 8, n. 3, p. 311-350, 1997.

Murphy, R. G. Capital mobility and the relationship between saving and investment in OECD countries. Journal of International Money and Finance, v. 3, p. 327-342, 1984.

. Productivity shocks, non-traded goods and optimal capital accumulation. European Economic Review, 30, p. 1081-1095, 1986.

Obstfeld, M.; Rogoff, R. The six major puzzles in international macroeconomics: is there a common cause?. NBER Working Paper 7777, 2000.

Obstfeld, M. Capital mobility in the world economy: theory and measurement. Carnegie-Rochester Conference Series on Public Policy, p. 1-24 Spring 1986. 
Phillips, P. C. B.; Hansen, B. E. Statistical inference in instrumental variables regression with I(1) processes. Review of Economic Studies, v. 57, n. 1, p. 99-125, 1990.

Sawada, Y. Are heavily indebted countries solvent? Tests of intertemporal borrowing constraints. Journal of Development Economics, 45, p. 325-37, 1994.

Sinn, S. Saving-investment correlations and capital mobility: on the evidence from annual data. Economic Journal, 102, p. 1162-1170, September 1992.

Summers, L. H. Tax policy and competitiveness. In: Frenkel, Jacob A. (ed.), International aspects of fiscal policy, NBER Conference Report, Chicago: Chicago University Press, 1988, p. 349-375.

Tesar, L. Saving, investment, and international capital flows. Journal of International Economics, 31, p. 55-78, 1991.

Tobin, J. Comment on "Domestic saving and international capital movements in the long run and short run, by M.S. Feldstein”. European Economic Review, 21, p. 53-156, 1983.

Wong, D. What do saving-investment relationships tell us about capital mobility? Journal of International Money and Finance, v. 9, p. 60-74, 1990. 